Research article

\title{
Energetic valorization of algal biomass in a hybrid anaerobic reactor
}

\author{
Paula Assemany ${ }^{a,}{ }^{*}$, Isabel de Paula Marques ${ }^{\text {b}}$, Maria Lúcia Calijuri a , \\ Teresa Lopes da Silva ${ }^{\text {b }}$, Alberto Reis ${ }^{\mathrm{b}}$ \\ ${ }^{a}$ Universidade Federal de Viçosa/Civil Department, Avenida PH Rolfs s/n, 36570-900, Viçosa, MG, Brazil \\ ${ }^{\mathrm{b}}$ LNEG, National Laboratory of Energy and Geology/Bioenergy Unit, Estrada do Paço do Lumiar 22, 1649-038, Lisbon, Portugal
}

\section{A R T I C L E I N F O}

\section{Article history:}

Received 5 October 2017

Received in revised form

13 December 2017

Accepted 20 December 2017

Available online 4 January 2018

\section{Keywords:}

Anaerobic digestion

Bioenergy

Flow cytometry

Microalgae

Waste valorization

\begin{abstract}
A B S T R A C T
This study evaluated the operation of a hybrid anaerobic reactor fed with algal biomass cultivated in effluent from the brewery industry. Three stages of operation were distinguished during the 72 days of semi-continuous functioning of the reactor: Stage $1(\mathrm{~S} 1)$, in which algal biomass was used as substrate; Stage 2 (S2), in which $10 \%(\mathrm{v} / \mathrm{v})$ of the algal biomass was substituted by olive mill wastewater (OMW); and Stage 3 (S3), in which algal biomass was heat pre-treated. During S1, a loss of solids was observed, with an increment of organic matter in the outlet. The substitution of $10 \%$ of the volume of algal biomass by OMW tripled the methane productivity obtained in the previous stage by digestion of pure algal biomass. Heat pre-treatment was not efficient in rupturing the cell wall, and consequently did not have any effect on the increase in biogas production. The complementarity of substrates in the assessed conditions led to better results than the pre-treatment of the algal biomass.
\end{abstract}

(c) 2017 Elsevier Ltd. All rights reserved.

\section{Introduction}

One of the most important processes for converting biomass into energy is anaerobic digestion, which consists of the biochemical conversion of organic matter into biogas. Anaerobic digestion technology presents great applicability for a wide range of substrates and is used all over the world. Biogas is capable of producing 20-300 kWh of net energy per tonne of substrate (European Commission, 2005) and the residual biomass after anaerobic digestion still contains mineralized nutrients, so it can be used as organic fertilizer after the energy production process (Vergara-Fernandez et al., 2008; Ward et al., 2008).

The capacity of microalgae to adapt and survive in a wide range of environments is enormous and their cultivation can be associated with the objectives of wastewater treatment and energy production. More recently, microalgae have emerged as a new substrate for the production of biofuels through anaerobic digestion. This potential for biogas production can be associated with the low lipid content of algae biomass grown in wastewaters and also with the possibility to use humid biomass, saving energetic and economical resources from the drying process.

\footnotetext{
* Corresponding author. Av. P.H. Rolfs, Centro de Ciências Exatas e Tecnológicas, Campus da Universidade Federal de Viçosa, Viçosa, MG 36570-900, Brazil.

E-mail address: paula.assemany@ufv.br (P. Assemany).
}

However, limitations arising from the algal biomass substrate are still currently described. The greater complexities of the anaerobic digestion of the algal biomass are reported as being the low algae cell wall digestibility and the inhibition of the process by the presence of ammonia due to high protein content (Mussgnug et al., 2010; Sialve et al., 2009). Advances still need to be made to consolidate the process and overcome those limitations. Therefore, studies focus on biomass co-digestion (Wang et al., 2013; RamosSuárez and Carreras, 2014) and pré-treatment methods (Alzate et al., 2012; Passos et al., 2013; Zhao et al., 2014).

The type of reactor selected to perform the anaerobic digestion is also an important factor in achieving good performance and economic viability of the process. Regarding anaerobic reactor configuration for algal biomass digestion, the performance of the continuous stirred tank reactor is still limited, but probably is the most used reactor type for this substrate digestion. A strategy that may be applied in order to overcome algal cell wall resistance, besides pre-treatments, is the use of more suitable reactors. The disassociation of hydraulic retention time and solids retention time may be a potential strategy (González-Fernández et al., 2015).

The hybrid anaerobic reactor is an ascending-flow fixed-bed reactor that combines the positive aspects of the up flow anaerobic sludge blanket (UASB) reactor and the anaerobic filter, namely the greater tolerance to high organic loads and the guarantee of lower losses of suspended solids. Consequently, the efficiency of the reactor increases as the treated effluent reaches a better quality 